\title{
Efesus trufanovi Simutnik gen. et sp.n. (Hymenoptera: Chalcidoidea: Encyrtidae) from late Eocene Danish amber
}

\section{Efesus trufanovi Simutnik gen. et sp.n. (Hymenoptera: Chalcidoidea: Encyrtidae) из позднеэоџенового датского янтаря}

\author{
S.A. Simutnik ${ }^{1}$, E.E. Perkovsky ${ }^{1}$, D.V. Vasilenko ${ }^{2,3}$ \\ С.А. Симутник ${ }^{1}$, Е.Э. Перковский ${ }^{1}$, А.В. Василенко ${ }^{2,3}$
}

\footnotetext{
${ }^{1}$ I.I. Schmalhausen Institute of Zoology, National Academy of Sciences of Ukraine, Kiev 01030, Ukraine. E-mail: sim@izan.kiev.ua, perkovsk@gmail.com.

${ }^{1}$ Институт зоологии им. И.И. Шмальгаузена НАН Украины, ул. Богдана Хмельницкого 15, 01030 Киев-30, Украина.

${ }^{2}$ Borissiak Paleontological Institute, Russian Academy of Sciences, Moscow 117647, Russia. E-mail: damageplant@mail.ru.

2 Палеонтологический институт им. А. А. Борисяка РАН, Москва 117647, Россия.

${ }^{3}$ Cherepovets State University, Lunacharsky prospect 5, Cherepovets 162600, Vologda region, Russia.

${ }^{3}$ Череповецкий государственный университет, пр. Луначарского 5, Череповец 162600, Вологодская обл., Россия.
}

KEY WORDS: Encyrtidae, Eocene, Danish amber, filum spinosum, cerci, fossils.

КЛЮЧЕВЫЕ СЛОВА: Encyrtidae, Еocene, датский янтарь, filum spinosum, пигостили, ископаемые.

ABSTRACT. Efesus trufanovi Simutnik, gen. et sp.n., is described and illustrated based on a female specimen from Danish amber collection of the Zoological Museum of University of Copenhagen. It is the eighth Danish amber hymenopteran genus unknown from Baltic amber. The new genus is characterized by the long double row of closing setae (filum spinosum) on distal margin of the linea calva of forewings, cerci are advanced towards the middle of gaster, hypopygium not reaching metasomal apex, parastigma not expanded, stigmal vein with long uncus. Such a long double row of the filum spinosum, consisting of nine setae, has not yet been described among the fossil encyrtids. The new genus is considered unplaced within subfamily Encyrtinae.

РЕЗЮМЕ. Efesus trufanovi Simutnik, gen. et sp.n. описан и проиллюстрирован по самке из коллекции датского янтаря Зоологического музея Копенгагенского университета. Это восьмой род гименоптер из датского янтаря, неизвестный из балтийского янтаря. Новый род характеризуется длинным двойным рядом замыкающих щетинок (filum spinosum) на дистальном крае голой косой полоски передних крыльев, пигостили продвинуты к середине брюшка, гипопигий не достигает вершины метасомы, парастигма не расширена, радиальная жилка с длинным ункусом. Такой длинный двойной ряд filum spinosum, состоящий из девяти щетинок, ещё не был описан у ископаемых энциртид. Новый род занимает неопределенное систематическое положение в подсемействе Encyrtinae.

\section{Introduction}

The presence or absence of filum spinosum is one of the characters used to separate the Encyrtidae into two subfamilies [Trjapitzin, 1967]. In the oldest known representatives of the family from the middle Eocene Sakhalinian amber the closing setae have not been found [Simutnik, 2014, 2015b]. Encyrtidae with filum spinosum are known only since late Eocene and already described from the Baltic, Danish, and Rovno amber [Simutnik et al., 2014; Simutnik, 2015a; Simutnik, Perkovsky, 2017, 2018a, c, 2020]. In the present paper, one more encyrtid with the distinctly developed filum spinosum is described.

\section{Material and methods}

The studied specimen is housed in the Zoological Museum of the University of Copenhagen (ZMUC). Lars Vilhelmsen (ZMUC) kindly arranged a loan of specimens. From this collection of Danish amber, Sulia glaesaria Simutnik, 2015, Protocopidosoma kononovae Simutnik, 2017 and Dencyrtus vilhelmseni Simutnik, 2018 have already been described. General information on the locality, age, and composition of the fauna from Danish amber were provided in works of Larsson [1978], Dlussky, Rasnitsyn [2009], Perkovsky [2011, 2016], Guénard et al. [2015], and Nadein et al. [2016].

How to cite this article: Simutnik S.A., Perkovsky E.E., Vasilenko D.V. 2020. Efesus trufanovi Simutnik gen. et sp.n. (Hymenoptera: Chalcidoidea: Encyrtidae) from late Eocene Danish amber // Russian Entomol. J. Vol.29. No.3. P.298-302. doi: 10.15298/rusentj.29.3.10 
The images were taken using a Leica Z16 APO stereomicroscope equipped with a Leica DFC 450 camera and processed with LAS V3.8 software. To improve imaging, we applied sucrose syrup of approximately the same refractive index as the amber itself and then placed a glass cover slip on top; after it syrup was removed by warm water. The images were then enhanced using Adobe Photoshop (brightness and contrast only).

Terminology and abbreviations follow Gibson [1997], Noyes et al. [1997], and Heraty et al. [2013]. The following abbreviations are used in the text and illustrations:

F1, F2, etc. - funicular segments 1, 2, etc.

$\mathrm{c}$ - cercus

fs - filum spinosum

lc - linea calva

mps - multiporous plate sensilla

Mt1, Mt2, etc. — metasomal terga, numbering starts from petiole (Mt1)

$$
\begin{aligned}
& \mathrm{n}-\text { notaulus } \\
& \mathrm{s}-\text { mesotibial spur } \\
& \mathrm{sp} \text { - mesothoracic spiracle }
\end{aligned}
$$

Family Encyrtidae Walker, 1837

Subfamily Encyrtinae Walker, 1837

\section{Genus Efesus Simutnik, gen.n.}

Type species. Efesus trufanovi Simutnik, sp.n.

DIAGNOSIS. Row of filum spinosum double, long, consisting of 9 setae; clava large, with rounded apex, as long as 5 preceding flagellomeres combined; notauli very short; parastigma only slightly widened; cerci advanced almost to middle of metasoma.

DESCRIPTION of female. Habitus as in Figs 1-3. Body compact, not flattening. Head slightly wider than thorax in dorsal view and approximately rounded in frontal view, hypognathous; occipital margin rounded; surface of frontovertex with polygonal reticulate sculpture, elongated on genae, without deep punctures (Fig. 1); ocelli large, in approximately right triangle; distance between posterior ocellus and eye margin (OOL) as posterior ocellar diameter; genae long, height of eye slightly larger than malar space (Fig. 2); scrobal depression deep, with sharp apical margin and small interantennal prominence, distance between apical margin of scrobal depression and anterior ocellus equal to POL (Fig. 6); eye bare, without hairsprings. Antenna 11-segmented (1:1:6:3); antennal scape slightly widened and flattened; pedicel conical, longer than first two flagellomeres; flagellum not flattened or widened, width of flagellomeres increases toward apex; F1 and F2 small, F1-F5 almost square, F6 slightly longer than width; clava with rounded apex, 3segmented, slightly wider than last flagellomere, about as long as 5 preceding flagellomeres combined; flagellum and clava covered with short hairs; at least F4-F6 and all 3 claval segments with mps (Fig. 6). Mesosoma. Pronotum in dorsal view short, transverse; mesoscutum wider than long, with very short notauli (Fig. 1 (n)); dorsum and ventrum with same polygonal reticulate sculpture; axillae large, with meeting inner angles; mesoscutum approximately as long as scutellum, convex; mesopleuron similarly sculptured; propodeum short. Appendages. Forewing without dark areas, hyaline; linea calva with 9 closing setae (filum spinosum) along distal margin and a row of long covering setae along proximal margin (Fig. 4, fs); submarginal vein with slightly widened parastigma (Fig. 4, p) and hyaline break; marginal vein 2.5 times as long as wide; stigmal vein straight, not curved, slightly longer than marginal vein, with distinct uncus; postmarginal vein 3 times as long as marginal vein; setae of marginal fringe short; coxae and legs with same reticulate sculpture, as thorax; tarsi five segmented; protibia with curved tibial spur; mesotibial spur thick, as long as mid basitarsus. Metasoma slightly shorter than mesosoma; cerci advanced almost to middle of metasoma (Fig. 5, c); 1-3 terga of gaster (Mt2-Mt4) direct and parallel, Mt5-Mt7 M-shaped, Mt8 Vshaped; all terga and sterna with polygonal reticulate sculpture; hypopygium transverse, not reaching apex of gaster (Fig. 3, hyp); ovipositor short, slightly protruding.

Male unknown.

SPECIES COMPOSITION. Type species.

ETYMOLOGY. "Efes" from fs - filum spinosum, with suffix "us". Gender masculine.

COMPARISON AND REMARKS. The new genus differs from all known fossil genera by the double row of filum spinosum and almost not expanded parastigma. Among the extant representatives, the double and long row of closing setae also rare. For example, in Coenocercus puncticollis Thomson the filum spinosum also consists of 2 rows of setae [Simutnik 2010, Fig. 1].

\section{Efesus trufanovi Simutnik, sp.n. \\ Figs $1-6$.}

MATERIAL. Holotype + , №15, ZMUC, 1-4-1970; B.V. Henningsen, Danish amber, late Eocene (deposited in ZMUC). The inclusion is situated close to the surface in a separate clear amber piece (about of 15:11:6 mm) of irregular coulomb shape.

Syninclusions absent.

DESCRIPTION. Body length, $1.4 \mathrm{~mm}$. Other reported measurements are relative, one micrometer division $=0.014$ $\mathrm{mm}$, and are approximate because of optical effects in the amber.

Colour. Body and legs dark, with a silver sheen (possibly due to a thin layer of air surrounding the inclusion), wings hyaline. Head. Relative measurements: head width (dorsal view) 31 , frontovertex minimal width 11 , anterior ocellus diameter 3, POL 5, distance between apical margin of scrobal depression and anterior ocellus 5.5, pedicel + funicle + clava 30 , pedicel 5 , clava length 12 , width 4.5 ; other proportions of antenna as in Fig. 6; distance between toruli 5, from torulus to eye margin 7. Mesosoma. Mesoscutum length 18, width 29; scutellum length 15 , width 17 ; proportions of veins and setation pattern as in Fig. 4. Metasoma. Length 40, distance between cercus and apex of Mt8 17.

ETYMOLOGY. The species is named after the zoologist and teacher Gennady Alekseevich Trufanov.

\section{Discussion}

Hymenopterofauna of Danish amber was never thoroughly studied, but first results of some revisions are enticing: e.g. myrmecofauna of the Danish amber is the most peculiar [Dlussky, Rasnitsyn, 2009; Perkovsky, 2016]. Three Danish ant genera and six species are unknown from Baltic amber. Six ant species unknown from northern coast of Subparathetys even seem not numerous in comparison with 15 Bitterfeld amber species unknown from Baltic amber [Dubovikoff et al., 2020], but only one genus and 6 species from these 15 
belong to the representative Bitterfeld amber collection of Humboldt Museum, Berlin (HMC) [Dlussky, Rasnitsyn, 2009; Dubovikoff et al., 2019].
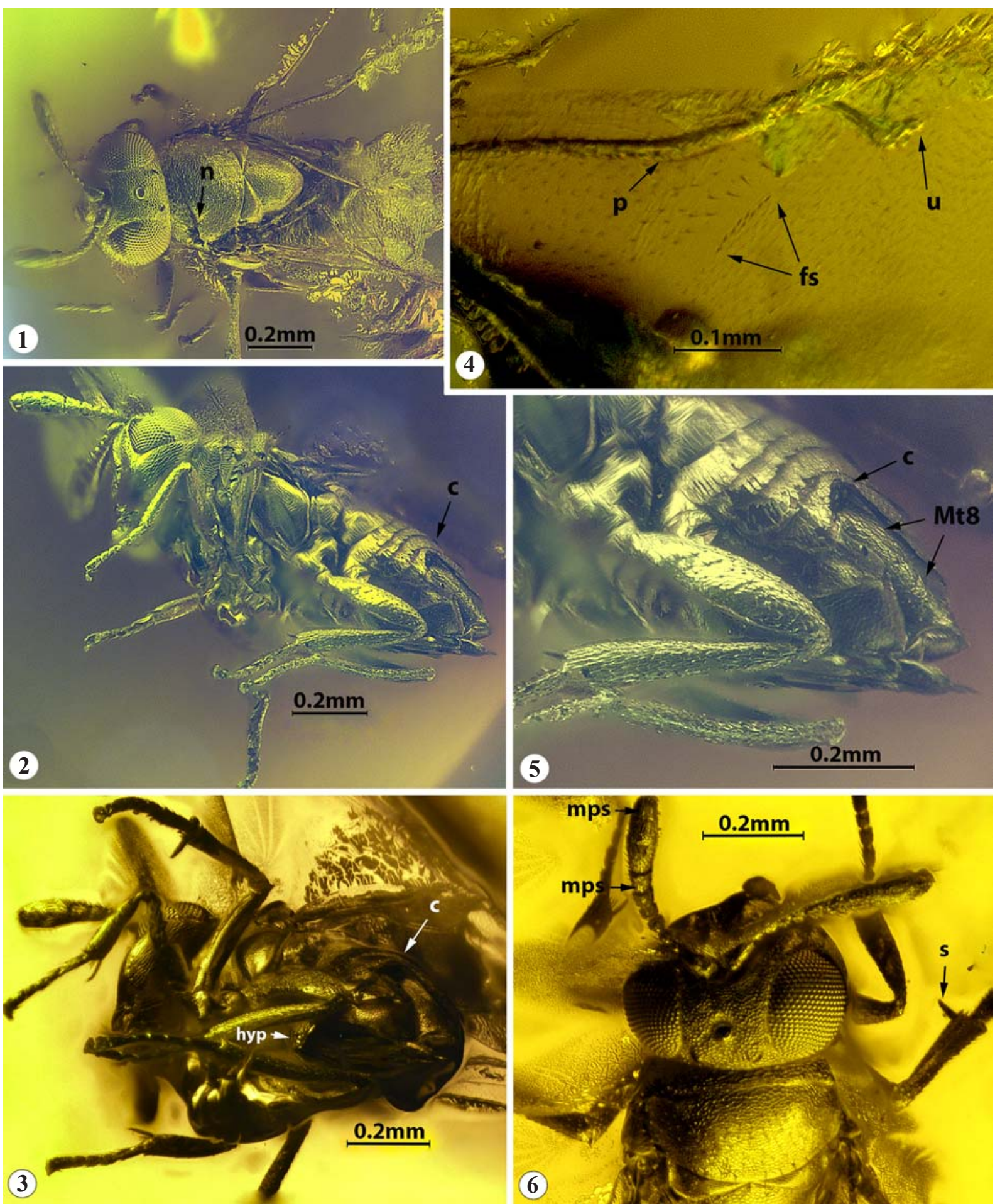

probability to find new ant species, because not less than $89 \%$ of specimens in all representative collections belong

Figs 1-6. Efesus trufanovi, gen. et sp.n., holotype + : 1-3 - habitus: 1, dorsal (n - notaulus); 2 - lateral (c - cercus); 3 - posterodorsal (hyp - hypopygium); 4 - forewing (fs - filum spinosum, $\mathrm{p}$ - parastigma, $\mathrm{u}$ - uncus); 5 - metasoma (Mt8 - last metasomal tergum); 6 - antennae (mps - multiporous plate sensilla), head, mesoscutum, mesotibial spur (s).

Рис. 1-6. Efesus trufanovi, gen. et sp.n., голотип + : 1-3 - общий вид: 1 - сверху (n - нотауля); 2 - сбоку (с — церка (пигостиль)); 3 - сзади и сбоку (hyp — гипопигий); 4 - переднее крыло (fs — filum spinosum, p — парастигма, u - ункус); 5 - метасома (Mt8 последний тергит); 6 - усики (mps - multiporous plate sensilla), голова, щит среднеспинки, шпора средней голени (s). 
to 20 species, known from all four Priabonian ambers [Dlussky, Rasnitsyn, 2009; Perkovsky, 2016, 2018, our unpublished data]. These 20 species are mostly dominant or at least permanent species of amber forests communities [Dlussky, Rasnitsyn, 2009]. Only 35 specimens of Danish amber ants from ZMUC (our data) do not belong to these 20 species, but $86 \%$ of mentioned specimens and $60 \%$ of mentioned species are unknown from Baltic amber. For comparison, ants from Bitterfeld amber representative collection (HMC) are 2.3 times more numerous than in ZMUC, and ants that not belong to 20 dominant and subdominant Priabonian species are 1.3 times more numerous ( 45 specimens, and 26 species, our data); but in HMC only $18 \%$ of these specimens and $24 \%$ of species are unknown from Baltic amber. From two species of Danish amber Dryinidae one is unknown from Baltic amber [Perkovsky, Olmi, 2018]; single Danish amber Bethylidae belongs to genus, unknown from Baltic amber [Ramos et al., 2014].

The relationships of fossil to modern genera within Encyrtidae have not yet been established. The filum spinosum is known only since late Eocene and not been found in the middle Eocene Encyrtidae from Sakhalinian amber [Simutnik, 2014, 2015b]. All known middle Eocene representatives, the earliest in the family, also differ by the expanded parastigma, the long veins of forewings, the presence of the long uncus at stigmal vein, and the apical position of the cerci (pygostyles in Russian literature). Majority of the known late Eocene Baltic, Rovno, and Danish amber encyrtids also retain the apical position of the cerci, expanded parastigma and rarely have filum spinosum [Simutnik, Perkovsky, 2006, 2015, 2017, 2018a-c, 2020]. Many of these directions of the morphological evolution of the family were predicted by V.A. Trjapitzin back in 1967 [Trjapitzin, 1967].

Thus, at this stage of research, it is possible to state that in the middle (Sakhalinian amber) and late Eocene (Baltic, Rovno and Danish amber) existed peculiar encyrtid faunas, different from each other and from extant fauna.

Acknowledgments. We are grateful to Lars Vilhelmsen (ZMUC) for an opportunity to study the material, to Alexandr P. Rasnitsyn (Borissiak Paleontological Institute) for discussion.

\section{References}

Dlussky G.M., Rasnitsyn A.P. 2009. Ants (Insecta: Vespida: Formicidae) in the Upper Eocene amber of Central and Eastern Europe // Paleontological Journal. Vol.43. No.9. P.1024-1042.

Dubovikoff D.A., Dlussky G.M., Perkovsky E.E., Abakumov E.V. 2019. A new species of the genus Eldermyrmex Shattuck, 2011 (Hymenoptera, Formicidae) from Bitterfeld amber (late Eocene) with species key of the genus // Paleontological Journal. Vol.53. No.10. P.994-997. https://doi.org/10.1134/S0031030119100046.

Dubovikoff D.A., Dlussky G.M., Perkovsky E.E., Abakumov E.V. 2020. [A new species of the genus Protaneuretus Wheeler (Hymenoptera, Formicidae) from Bitterfeld amber (late Eocene) with species key of the genus] // Paleontologicheskii Zhurnal. 2020. No.4. P.67-69 [in Russian, English translation: Paleontological Journal. Vol.54. No.4. P.389-391].
Gibson G.A.P. 1997. Chapter 2. Morphology and terminology // Gibson G.A.P., Huber J.T., Woolley J.B. (eds.). Annotated keys to the genera of Nearctic Chalcidoidea (Hymenoptera). NRC Research Press. Ottawa. P.16-44.

Heraty J.M., Burks R.A, Cruaud A., Gibson G.A., Liljeblad J., Munro J., Rasplus JY., Delvare G., Janšta P., Gumovsky A. et al. 2013. A phylogenetic analysis of the megadiverse Chalcidoidea (Hymenoptera) // Cladistics. Vol.29. P.466-542.

Guénard B., Perrichot V., Economo E.P. 2015. Integration of global fossil and modern biodiversity data reveals dynamism and stasis in ant macroecological patterns // Journal of Biogeography. Vol.42. No.12. P.2302-2312

Larsson S.G. 1978. Baltic amber - a paleobiological study // Entomonograph. Vol.1. P.1-192.

Nadein K.S., Perkovsky E.E., Moseyko A.G. 2016. New Late Eocene Chrysomelidae (Insecta: Coleoptera) from Baltic, Rovno and Danish ambers // Papers in Palaeontology. Vol.2. No.1. P.117137.

Noyes J.S., Woolley J.B., Zolnerowich G. 1997. Chapter 8. Encyrtidae // Gibson G.A.P., Huber J.T., Woolley J.B. (eds.). Annotated keys to the genera of Nearctic Chalcidoidea (Hymenoptera). NRC Research Press. Ottawa. P.170-320.

Perkovsky E.E. 2011. Syninclusions of the Eocene winter ant Prenolepis henshei (Hymenoptera: Formicidae) and Germaraphis aphids (Hemiptera: Eriosomatidae) in Late Eocene Baltic and Rovno amber: Some implications // Russian Entomological Journal. Vol.20. No.3. P.303-313.

Perkovsky E.E. 2016. Tropical and Holarctic ants in Late Eocene ambers // Vestnik zoologii. Vol.50. No.2. P.111-122.

Perkovsky E.E. 2018. Only a half of species of Hymenoptera in Rovno amber is common with Baltic amber // Vestnik zoologii. Vol.52. P.353-360. https://doi.org/10.2478/vzoo-2018-0037.

Perkovsky E.E., Olmi M. 2018. Discovery of the first pincer wasp (Hymenoptera, Dryinidae) from Rovno amber // Zootaxa. Vol.4457. No.2. P.296-304. https://doi.org/10.11646/zootaxa.4457.2.5.

Ramos M.S., Perkovsky E.E., Rasnitsyn A.P., Azevedo, C.O. 2014. Revision of Bethylinae fossils (Hymenoptera: Bethylidae) from Baltic, Rovno and Oise amber, with comments on the Tertiary fauna of the subfamily // Neues Jahrbuch für Geologie und Paläontologie, Abhandlungen. Vol.271. P.203-228. https:// doi.org/10.1127/0077-7749/2014/0385.

Simutnik S.A. 2010. [Finding of Coenocercus puncticollis (Hymenoptera, Chalcidoidea, Encyrtidae), a representative of new species and genus for the fauna of Ukraine] // Zoologicheskii Zhurnal. Vol.89. No.3. P.382-384 [in Russian].

Simutnik S.A. 2014. [First record of Encyrtidae (Hymenoptera, Chalcidoidea) from the Sakhalin Amber] // Paleontologicheskii Zhurnal. No.6. P.46-49 [in Russian, English translation: Paleontological Journal. Vol.48. No.6. P.621-623]. https://doi.org/ $10.1134 / \mathrm{S} 0031030114060124$.

Simutnik S.A. 2015a. A new fossil genus of Encyrtidae (Hymenoptera: Chalcidoidea) from Late Eocene Danish amber // Russian Entomological Journal. Vol.24. No.1. P.73-75.

Simutnik S.A. 2015b. [Description of two new monotypic genera of encyrtid wasps (Hymenoptera, Chalcidoidea: Encyrtidae), based on males from the Middle Eocene Sakhalin amber] // Entomologicheskoe Obozrenie. Vol.94. No.2. P.463-466 [in Russian, English translation: Entomological Review. Vol.95. No.7.P.937940]. https://doi.org/10.1134/S0013873815070118.

Simutnik S.A., Perkovsky E.E. 2006. A description of the encyrtoid male with archaic structure of metasoma (Hymenoptera, Chalcidoidea, Encyrtidae) from Rovno amber // Vestnik Zoologii. Vol.40. No.6. P.283-286. http://www.v-zool.kiev.ua/pdfs/2006/3/12.

Simutnik S.A., Perkovsky E.E. 2015. [Rovnosoma gen. nov. (Hymenoptera, Chalcidoidea, Encyrtidae) from the Late Eocene Rovno amber] // Paleontologicheskii Zhurnal. No.1. P.35-36 [in Russian, English translation: 2015. Paleontological Journal. Vol.49. No.1. P.36-38]. https://doi.org/10.1134/ S0031030115010116.

Simutnik S.A., Perkovsky E.E. 2017. [Protocopidosoma gen. nov. (Hymenoptera, Chalcidoidea, Encyrtidae) from the Late Eocene Danish amber] // Paleontologicheskii Zhurnal. No.3. P.64-65 
[in Russian, English translation: 2017. Paleontological Journal. Vol.51. No.3. P.288-290].

Simutnik S.A., Perkovsky E.E. 2018a. [Dencyrtus gen. nov. (Hymenoptera, Chalcidoidea, Encyrtidae) from the Late Eocene Danish amber] // Paleontologicheskii Zhurnal. No.3. P.67-68 [in Russian, English translation: 2018. Paleontological Journal. Vol.52. No.3. P.290-293].

Simutnik S.A., Perkovsky E.E. 2018b. [Trjapitzion Simutnik, gen. n. (Hymenoptera, Chalcidoidea: Encyrtidae), a new genus of encyrtid wasps from the Late Eocene Rovno amber] // Entomologicheskoe Obozrenie. Vol.97. No.3. P.539-544 [in Russian, English translation: 2018. Entomological Review. Vol.98. No.8 P.1152-1156]. https://doi.org/10.1134/S0013873818080225 Simutnik S.A., Perkovsky E.E. 2018c. Archaeocercus gen.nov. (Hymenoptera, Chalcidoidea, Encyrtidae) from Late Eocene
Rovno amber // Zootaxa. Vol.4441. No.3. P.543-548. https:// doi.org/10.11646/zootaxa.4441.3.8

Simutnik S.A., Perkovsky E.E. 2020. Ektopicercus Simutnik gen. nov. (Hymenoptera, Chalcidoidea, Encyrtidae) from late Eocene Rovno amber // Palaeoentomology. Vol.3. No.4. P.342-346. https://doi.org/10.11646/palaeoentomology.3.4.3

Simutnik S.A., Perkovsky E.E., Gumovsky A.V. 2014. [Review of the Late Eocene Encyrtidae (Hymenoptera, Chalcidoidea) with a description of the first fossil genus with filum spinosum] // Paleontologicheskii Zhurnal. No.1. P.65-74 [in Russian, English translation: Paleontological Journal. Vol.48. No.1. P.65-73].

Trjapitzin V.A. 1967. [The Problems of Morphological Evolution and the Classification of the Family Encyrtidae (Hymenoptera, Chalcidoidea)] // Chteniya pamyati N.A. Kholodkovskogo. Leningrad. P.44-62 [in Russian]. 